\title{
Modification of the International Energy Agency Model (the IEA Model of Short-term Energy Security) for Assessing the Energy Security of Ukraine
}

\author{
Taulant Salihaj \\ MS, Secundarschule Kreis Marthalen, Canton of Zurich, Switzerland \\ Svitlana Pryimenko
}

PhD, Assistant, Department of Economics and Business Administration, Sumy State University, Ukraine

\begin{abstract}
Over the past decades, as a result of global environmental, energy and economic crises, the level of development of the fuel and energy complexes in the world has become one of the dominant factors determining the level of national security, the country's competitiveness in the world market and its economic stability. At the same time, today the level of environmental and natural and technogenic safety of energy companies is extremely low in the world. Taking this into account, scientists and representatives of state authorities of various countries of the world, as well as intergovernmental associations and international organizations discuss the problem of searching for innovative sources of electric power generation for obtaining new types of energy products that can change innovative sources of electricity production and the global economy as a whole, and will increase the rationality of resource use and environmental safety of the country, regions and people.
\end{abstract}

Keywords: energy security, energy resources, ecological safety, resource use, risks.

JEL Classification: Q01, Q42, Q43, Q55.

(C) The Authors, 2017. This article is published with open access at ARMG Publishing.

\section{Introduction}

For quite a long period of time, it was generally accepted that the energy security of any country directly depends on oil imports (exports). However, today it is proved that there are a number of other factors that also have a significant impact on the state's energy security state. For example, droughty weather conditions negatively affect the operation of hydroelectric power stations, extreme natural phenomena lead to an increase in the use of electrical or thermal energy. The International Energy Agency recommends that, while assessing the level of energy security of the country, it should be guided not only by the volumes of oil supplies, but also by other criteria.

The IEA defines energy security as the uninterrupted availability of energy sources at an affordable price. Energy security has many aspects: long-term energy security mainly deals with timely investments to supply energy in line with economic developments and environmental needs. On the other hand, short-term energy security focuses on the ability of the energy system to react promptly to sudden changes in the supplydemand balance (See https://www.iea.org/topics/energysecurity/).

Bob Tippee (2012) ${ }^{1}$ defines the following factor of energy security:

$>$ Affordability.

$>$ Environmental acceptability. Most conversations about energy treat the environment and security as discrete matters to be dealt with accordingly.

$>$ Durability of supply. Security means energy flows can withstand and adapt to the interruption of supply. The threat to energy flows can take many forms. In the past few years, major disruptions have come from hurricanes, revolutions, labor strikes, and war.

$>$ Diversification of source.

$>$ Sufficiency relative to demand.

$>$ Relationship with water. As an issue of supply security, water is at least as pressing as energy. Increasingly, the two issues are linked. Meeting the world's growing demand for fresh water requires rising

\footnotetext{
${ }^{1}$ See http://www.ogj.com/articles/print/vol-110/issue-1c/regular-features/journally-speaking/defining-energy-security.html.
} 
amounts of energy. Meeting growing demand for energy requires rising amounts of water. Arid countries understand these relationships.

$>$ Equity among nations. Some countries have lots of oil, some lots of money, and some lots of both. Some countries have little of either but lots of hungry people. This is a security problem.

$>$ Relationships among nations.

$>$ The morality of consumption. That the morality of consumption came up in a discussion about energy security that encompassed elements such as equity among nations, water, and the environment was interesting.

This paper is organized as follows. Section 2 explains the rationale and the principles for the application of the IEA model of short-term energy security in Ukraine. Section 3 describes the evaluation tools and findings of energy security assessment. Section 4 presents our conclusions.

\section{The IEA model of short-term energy security}

The principles of the development of energy industry in the context of the impact on the environment and environmental safety of socio-economic development of society are laid in the scientific works of such scientists as E. Benz, J. Jewell, K. Hoffmann, S. Trek, S. Hunt, G. Shuttleworth, I., Farah, P., Rossi, B. K. Sovacool, M. A. Brown, et al.

The specialists of the International Energy Agency, in particular D. Jewell, have developed a model of a short-term energy security, which allows us to assess the vulnerability of energy systems of different countries to the occurrence of interruptions in the supply of certain types of energy resources (Jewell, 2011). The purpose of this model is to assess the security of supply of individual sources and fuels, and not to compare the security of supply of electric energy by various suppliers. Using this model cannot assess the safety of solar, wind and ocean energy production because of its focus on assessing the security of energy supplies.

The analysis of relevant literature on the problems studied has shown that the most urgent problem for scientists today is the search for methods for quantifying the level of energy security. The researchers of energy danger occurrence most often consider such types:

$>$ risks of insufficient energy resources in the country under study (geological risks);

$>$ the risks of energy resources inaccessibility (geopolitical and economic risks),

$>$ risks of negative impact on recipients (environmental and social risks).

According to the methodology of short-term energy security, the country's power system is assessed by three criteria:

$>$ the reliability of the energy system (sufficiency and reliability of resources and infrastructure);

$>$ the sovereignty of the energy system (the threat of interruptions in the supply of energy resources by foreign entities);

$>$ the stability of the energy system (the ability of the power system to respond to destructive impacts over a long period).

The short-term energy security model distinguishes external risks associated with energy imports, as well as internal risks associated with energy production, transformation and distribution (Table 1).

Table 1. Types of risks and characteristics of the economy, allowing them to compensate in accordance with the model of short-term energy security

\begin{tabular}{|c|l|l|}
\hline Risks & \multicolumn{1}{|c|}{ The essence of risks } & $\begin{array}{c}\text { Characteristics of the reaction of the country's energy } \\
\text { system to the occurrence of risk }\end{array}$ \\
\hline External & $\begin{array}{l}\text { Risks related to interruptions in the process of energy } \\
\text { import }\end{array}$ & $\begin{array}{l}\text { The ability of the country's energy system to respond } \\
\text { to interruptions in energy import, replace suppliers and } \\
\text { supply routes }\end{array}$ \\
\hline Internal & $\begin{array}{l}\text { Risks associated with obsolete equipment at power plants, } \\
\text { heating systems and imperfect mechanisms for converting } \\
\text { energy resources to an energy product. }\end{array}$ & $\begin{array}{l}\text { The ability of the country's energy system to respond } \\
\text { to interruptions in supply }\end{array}$ \\
\hline
\end{tabular}

Source: Lamben (1996).

According to the Jewel's model for assessing the country's energy security, ranges of values for each type of risk are determined in accordance with the regulatory framework of the International Energy Agency. For example, three ranges of risk values for a country's dependence on energy import are identified as low de- 
pendence $(\leq 15 \%)$, moderate dependence (40-65\%), high import dependence $(\geq 80 \%)$. According to the model of short-term energy security, it should be estimated for each country for each type of energy resource.

Let us consider separately the specifics of the assessment of the level of risk of interruptions in the supply of each type of energy resource in accordance with the short-term model of energy security. First, weconsider the risks of interruptions in the supply of crude oil. The most important indicator is the dependence of the country under study on its import. The level of political stability is estimated in points from 0 to 7 (the most unstable countries receive 7 points, stable -0 points).

Also, the level of energy security is affected by the presence in the country of research of a sufficient number of ports, pipelines for the import of energy resources, and the possibility of the country being investigated to diversify suppliers. Thus, crude oil is imported on ferries or pipelines. The more entry points the country has, the less is its energy system vulnerable to supply disruptions. These risk ranges of crude oil import sources are singled out in the short-term model of energy security:

1. low risk - 5-9 pipelines / more than five ports;

2. medium risk - the presence of 2-4 ports or 3-4 pipelines;

3. high risk - the presence of 1 port or 1-2 pipelines.

Today, in Ukraine, there are three subsidiaries involved in the transportation of crude oil: PJSC UkrTransGas, JSC Ukrtransnafta, JSC Ukrspettransgaz. Also, Ukraine has 18 sea trading ports: BilhorodDnistrovskyi, Berdiansk, Dnipro-Buz, Evpatoria, Izmail, Ilyichevsk, Kerch, Mariupol, Mykolaiv, Odessa, Oktiabrsk, Ochakiv, Reni, Sevastopol, Skadovsk, Ust-Danube, Feodosia, Kherson, Pivdennyi, Yalta.

The level of diversification of suppliers of crude oil can be estimated by the Herfindahl-Hirschman index, used to assess the degree of monopolization of the industry. In this case, it is calculated as the sum of squares of the shares of each supplier in the total supply of crude oil to the country under study. This indicator ranges from 0.1 (high level of competition) to 1.0 (monopoly).

Today, there is a risk to obtain oil refining technologies of a low level. If before the indicator of processing depth (production volume, efficiency, etc.) was used to characterize the level of technological production, today the Nelson complexity index is used. It defines the potential for secondary processing of petroleum products for the primary processing of crude oil, which is taken as a basis and equals to 1 (Jakovetz, 1984; Reimers, 1990). This index, introduced in 1960 by Wilber Nelson, is calculated by summing the complexity coefficients of technological processes, multiplied by the capacity of the refinery. For oil refineries in the United States in 2010 the Nelson complexity index was 9.5, and for European countries - 6.5 (these values are higher than the world average value of 5.9) (Barinov, et al., 2004).

Next, let's consider the risks of interruptions in the supply of petroleum products. In Ukraine oil products are imported by means of such railway crossing points:

$>$ crossing points of the Belarusian-Ukrainian border through the railway;

$>$ railway stations: Goryn - Udryck villages, Teryuha -Gornostaiivka villages, Terekhovka urban village Horobychi village, Slovechno - Berezhest' villages;

$>$ the point of transition of the Polish-Ukrainian border (from Poland) through the railway station Mostyska 2 (Mostyska village);

$>$ the point of transition of the Polish-Ukrainian border (from Hungary) through the railway station of Bat'evo;

$>$ the point of transition of the Russian-Ukrainian border through the railway station in Kupiansk (see http://www.iea.org/publications/freepublications/publica-tion/biomass.pdf).

Today there are 6 oil refineries in Ukraine: Nadvirnianskyi (Nadvirna, Ivano-Frankivsk region), Drogobychskyi (Drohobych, Lviv region), Shebelinskyi (Kharkov region), Kremenchuts'kyi (Kremenchuk, Poltava region), Odes'kyi (Odessa region.), Lisichanskyi (Lugansk region), Khersonskyi (Kherson region). The volume of import of petroleum products to Ukraine ranged from $45-65 \%$ in 2014. Today, Ukraine produces 558 thousand tons of kerosene; 556 thousand tons of kerosene are imported and 89 thousand tons of kerosene are exported. The shares of individual countries in the total volume of import of petroleum products to Ukraine are shown in Figure 1. Since different types of petroleum products are not interchangeable in 
most cases, the analysis of energy security is carried out for each type separately (gasoline, diesel fuel, fuel oil, etc.).

Source: Barinov et al. (2004).

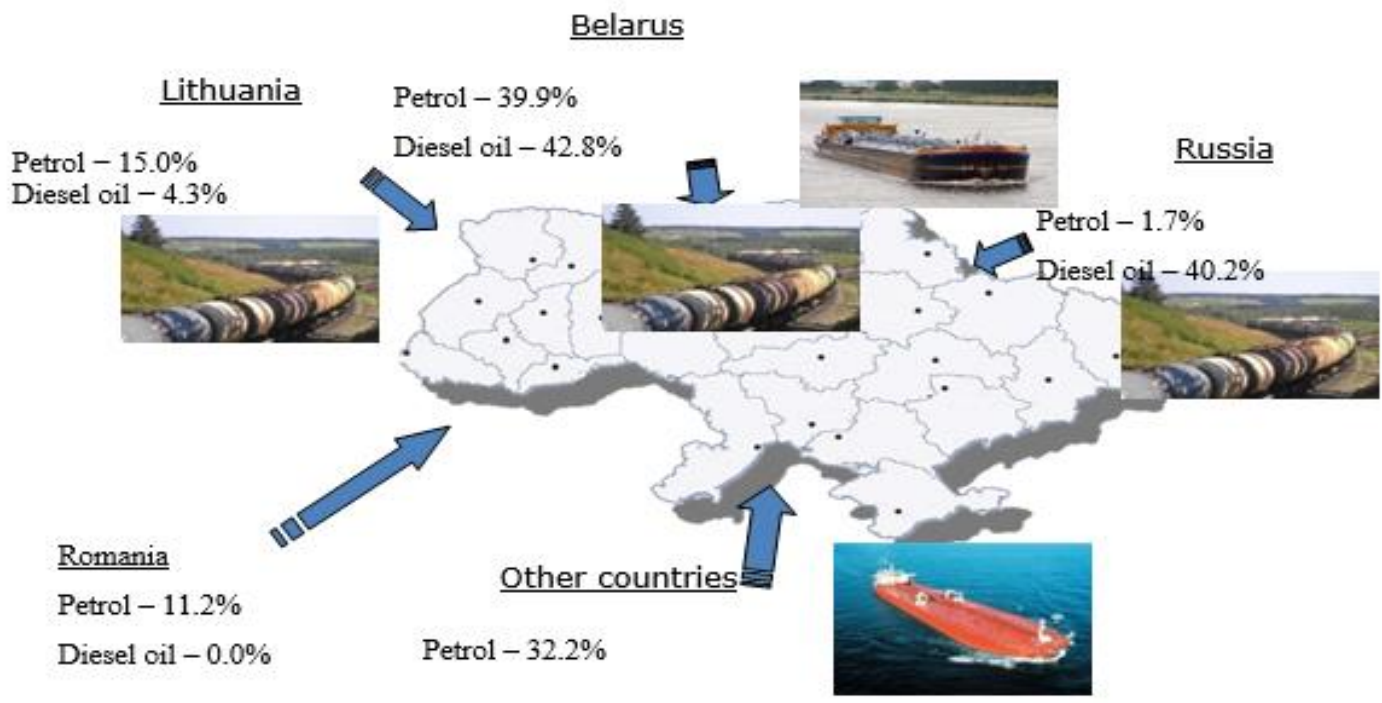

Figure 1. The shares of individual countries in total import of petroleum products to Ukraine in 2015

Source: Farah et al. (2015).

The average prices for the final consumption of certain types of oil products in different countries of the world are presented in Table 2.

Table 2. Average prices for final consumption of certain types of oil products in different countries of the world (as of January 2015)

\begin{tabular}{|c|c|c|c|}
\hline Country & $\begin{array}{c}\text { Petrol, } \\
\text { dollars for 1 liter }\end{array}$ & $\begin{array}{c}\text { Diesel fuel, } \\
\text { dollars for 1 liter }\end{array}$ & $\begin{array}{c}\text { Fuel oil, } \\
\text { per 1000 liters }\end{array}$ \\
\hline France & 1.50 & 1.10 & 809.07 \\
\hline Germany & 1.52 & 1.13 & 691.31 \\
\hline Italy & 1.72 & 1.33 & 1380.64 \\
\hline Spain & 1.33 & 1.05 & 751.11 \\
\hline United Kingdom & 1.64 & 1.46 & 780.33 \\
\hline Japan & 1.26 & 1.08 & 987.87 \\
\hline Canada & 0.78 & 0.94 & 742.60 \\
\hline USA & 0.56 & 0.79 & 342.09 \\
\hline Ukraine & 1.07 & 1.05 & \\
\hline
\end{tabular}

Source: see http://expert.ru/ratings/table_531121/.

The most significant indicator in assessing the level of energy security for natural gas supplies under the short-term model of energy security is the dependence of the country under study on importing countries. The more the country supplies energy resources, the more competitive conditions develop between importers and exporters. Information on production, consumption, import and export of natural gas in various countries of the world is presented in Table 3. The coal industry, unlike the gas industry, is energetically independent in Ukraine because of coal surplus (100\% security) (Rutledge, 2006). There are 6 railways in Ukraine which transport coal to neighboring countries: Lvivska, Pivdenno-Zakhidna, Odeska, Prydniprovska, Pivdenna, Donetska railways. Ukraine is one of the largest countries in the world for the production of coal. In 2014, 61.8 Mt of coal was mined here, thus Ukraine took the 14th place in the world in terms of the amount of coal mined (China took the first place (3 $471.1 \mathrm{Mt}$ of coal), the second place belonged to the USA (1 $004.1 \mathrm{Mt}$ of coal), the third - to India (585.9 Mt of coal), and the fourth - to the Russian Federation (333.8 Mt of coal)) (see https://www.iea.org/media/presentations/Ukraine Russia Europe Gas Oil Factsheet.pdf). In period January-May 2015, Ukraine produced 53.7\% less compared to the same period in 2014 (see http://www.iea.org/topics/energysecurity/). Coal fields in Ukraine are shown in Figure 3. Ukraine has many sources for biomass energy. Biomass fuels are wood 
waste (sawdust, shavings, bark) and agricultural waste (straw from barley, oats, corn, sunflower). First, these wastes are split or crushed, and then delivered to power plants, where they are used as an energy resource for obtaining electrical and thermal energy.

Table 3. Volumes of production, consumption, import and export of natural gas in the countries of the world

\begin{tabular}{|c|c|c|c|c|c|c|}
\hline Country & $\begin{array}{l}\text { Natural gas } \\
\text { extraction, } \\
\mathrm{mln} \mathrm{m}^{3}\end{array}$ & $\begin{array}{l}\text { Natural gas } \\
\text { consumption, } \\
{\text { mln } \mathrm{m}^{3}}^{\text {nat }}\end{array}$ & $\begin{array}{l}\text { Natural gas } \\
\text { consumption, in } \\
\text { power industry, } \\
\text { mln } \mathrm{m}^{3}\end{array}$ & $\begin{array}{c}\text { Natural gas } \\
\text { consumption by electric } \\
\text { power industry, } \%\end{array}$ & $\begin{array}{c}\text { Natural gas } \\
\text { import, } \mathrm{mln}^{3}{ }^{3}\end{array}$ & $\begin{array}{l}\text { Natura 1 gas } \\
\text { export, mln } \mathrm{m}^{3}\end{array}$ \\
\hline France & 563 & 41205 & 8684 & 21 & 46065 & 4877 \\
\hline Germany & 11903 & 77597 & 24006 & 31 & 87350 & 19694 \\
\hline Italy & 8449 & 77917 & 34009 & 44 & 70369 & 124 \\
\hline Japan & 3333 & 123498 & 64250 & 52 & 116455 & - \\
\hline Poland & 6247 & 17171 & 1651 & 10 & 11790 & 29 \\
\hline Slovenia & 2 & 906 & 193 & 21 & 904 & - \\
\hline Spain & 52 & 33555 & 16994 & 51 & 35489 & 1698 \\
\hline United Kingdom & 47594 & 82622 & 35797 & 43 & 53447 & 16555 \\
\hline USA & 651293 & 690056 & 225890 & 33 & 97791 & 42678 \\
\hline $\begin{array}{l}\text { Republic of } \\
\text { Belarus }\end{array}$ & 222 & 20220 & 1651 & 10 & 19998 & - \\
\hline $\begin{array}{l}\text { Russian } \\
\text { Federation }\end{array}$ & 677010 & 474306 & 270851 & 57 & - & 28955 \\
\hline Ukraine & 20294 & 56442 & 19258 & 34 & 44037 & - \\
\hline
\end{tabular}

Source: see https://www.iea.org/media/presen-tations/Ukraine_Russia_Europe_Gas_Oil_Factsheet.pdf.

\section{Energy security assessment}

Today $13.8 \%$ of electric power is generated by nuclear power, and $50.06 \%$ in Ukraine (Jakovetz, 1984). By 2050 the world plans to increase the production of nuclear power in $1200 \mathrm{GW}$ (by 24\%) (Figure 2), which requires additional investments in infrastructure and personnel qualification, expansion of nuclear fuel supplies while maintaining high quality and safety standards (Tsikavyi, 2016).

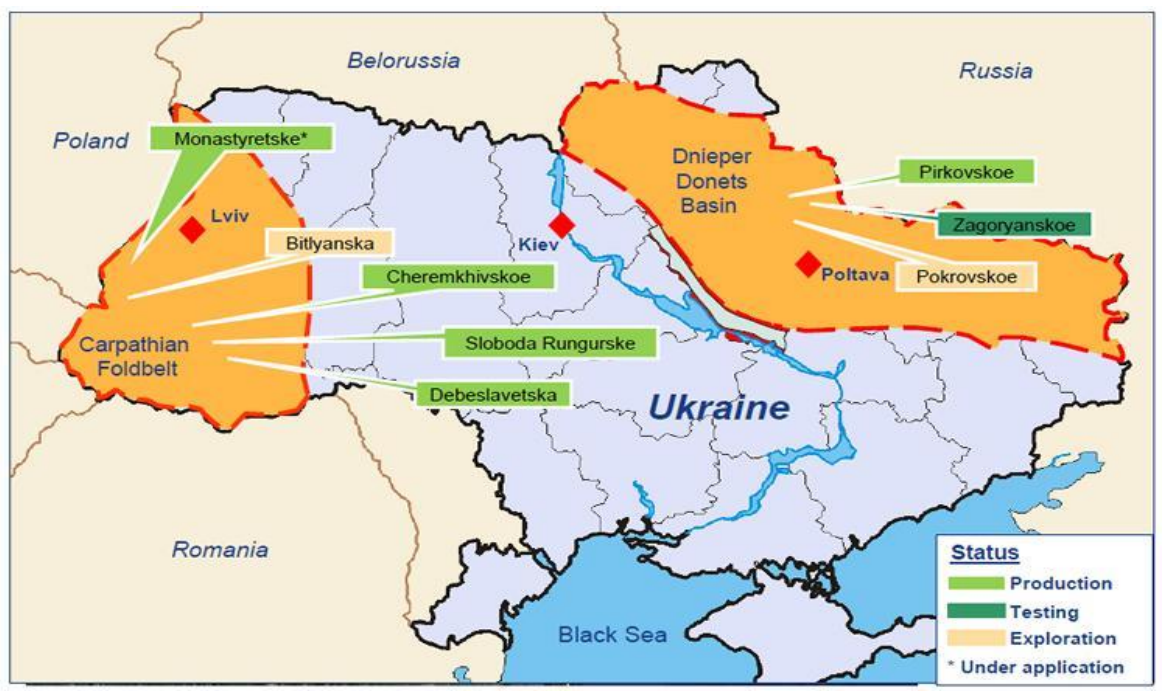

Figure 2. Natural gas fiends in Ukraine

Source: Tsivatyi V.G. (2016).

The level of danger of nuclear energy in the country is measured by the Nelson index. If a technological error has led to a malfunction in the operation of a particular type of reactor, then it is necessary to stop all other reactors to correct a similar error and carry a power outage. Thus, the short-term model of energy security provides an opportunity to assess energy security in the supply of seven types of primary energy resources and two types of secondary fuels (biomass and waste). After assessing the level of risk of each type and the response to them, the countries are grouped according to the values of indicators. This model allows to determine the level of energy security of the country for each type of energy resource on the basis of the ratio of risk values and the ability of the country's economy to compensate for these risks. In developing the 
authors approach to assessing the level of danger from factors affecting the supply disruptions of the basic energy resource for the relevant technology of energy production, the list of factors influencing the supply terms of the dominant energy resource by the short-term model of energy security was adopted as a basis. These factors include: the type of energy resource, its technical, economic, environmental characteristics, as well as the level of political stability, which affects the terms of its supply. However, this method did not take into account the effect of natural resources and environmental factors, and it does not have a final integrated estimate. Our proposals are based on the use of a list of indicators for the model under study and a reassessment of their marginal levels, using the scoring method of estimation $-0,1,2$ points (Table 3 ). The calculation of overall level of the country's energy security from possible interruptions in the supply of a basic energy resource for the relevant technology for the production of an energy product $(D)$ is as follows

$D=\frac{S c}{S c^{\max }}$

where $S_{c}$ is the total score, characterizing the level of danger calculated for the country under study; $S_{c}{ }^{\max }-$ the maximum possible total score, characterizing the level of danger in the country under study (Table 1 in Appendix). While calculating the overall level of the country's energy security from the occurrence of disruptions in the supply of the basic energy resource, we made a hypothesis on the equivalence of all internal and external risks.

Table 4. Assessing the overall level of the country's energy security from possible disruptions in the supply of a basic energy resource

\begin{tabular}{|c|c|c|c|c|}
\hline & Type of energy resource & $S c^{\max }$ & $S c$ & $D$ \\
\hline 1 & Raw oil & 16 & 12 & 0.75 \\
\hline 2 & Oil products & 16 & 9 & 0.56 \\
\hline 3 & Natural gas & 16 & 2 & 0.69 \\
\hline 4 & Coal & 10 & 0 & 0.5 \\
\hline 5 & Biomass & 4 & 1 & 0 \\
\hline 6 & Biofuels & 8 & 0 & 0.13 \\
\hline 7 & Water resource & 2 & 7 & 0 \\
\hline 8 & Nuclear fuel & 12 & & 0.58 \\
\hline
\end{tabular}

As it can be seen, the technology for obtaining energy from biomass and water is absolutely safe $(\mathrm{D}=0)$. There most dangerous for Ukrainian economy technologies are used for obtaining an energy product from oil products and crude oil.

\section{Conclusions}

Authors offer a scientific and methodical approach that allows us to assess the overall level of energy security of the country from possible disruptions in the supply of basic energy resources from the factors that affect the conditions for the supply of energy resources and can become the basis in the decision-making process for further development of appropriate technology for the production of energy resources.

Today in Ukraine there are practically no active projects aimed not at modernizing the energy sector. if individual projects are implemented, then this occurs primarily in the public sector at the expense of the funds of international financial organizations that help Ukraine in the way of reforms. Such inactivity is primarily related to the imperfection of the legislation, simply not more sophisticated mechanisms for implementing many types of projects in this region, and does not give private investors any guarantees of the return of their funds. In this regard, the main types of legal services in this direction is advising on attracting funding from international creditors and work on draft laws, are designed to create the prerequisites for the implementation of more projects on energy efficiency.

Based on the analysis of the degree of deterioration of the main equipment of power plants and the environmental and economic consequences of the eco-destructive effect of their work, it is established that it is necessary to determine the optimal replacement period for the equipment of power plants, in calculating which, in addition to the usual economic costs, ecological and economic costs, in particular, the costs and indirect losses from pollution of the environment with wastes that occur at various stages of the life cycle of the power plant a product; to carry out current environmental payments; land reclamation and landfilling; to 
eliminate possible man-made accidents. The proposed approach provides for minimization of integral specific discounted environmental and economic costs and allows determining the remaining operating time of a particular power plant.

Over the past years, Ukraine has launched a profound market transformation. But we still face challenges, which must be overcome on the way to ensuring the energy independence. It is about further diversification of energy sources and ways of their delivery, creation of strategic reserves, increase in the level of extraction of energy resources, reduction of their consumption and their effective use, development of competitive and transparent markets for electricity, natural gas and heat, coal, oil and oil products, ensuring the reliable functioning of the energy infrastructure, taking into account the protection of critical facilities.

\section{References}

1. Barinov, B. A. et al. (2004). Nadezhnost' liberalizovannykh sistem energetiki [Reliability of liberalized energy systems]. Novosibirsk: Nauka, 333 p.

2. Bioenergy Project Developent Biomass Supply. Official site IEA. Available at http://www.iea.org/publications/freepublications/publica-tion/biomass.pdf.

3. Coal information according to data of 2015. Official site IEA. Available at http://www.iea.org/media/training/presen-tations/statisticsmarch/coalinformation.pdf.

4. Esli neft' budet stoit' $\$ 50$, to stoimost' gaza upadet do $\$ 120$ [If oil 'will cost' $\$ 50$, then the cost of gas will drop to \$120]. Available at http://104.ua/ru/news/id/jakscho-nafta-koshtuvatime-50-to-vartist-gazuvpad-8903.

5. Facts in Brief: Russia, Ukraine, Europe, Oil \& Gas, 4 March 2015. Official site IEA. Available at https://www.iea.org/media/presen-tations/Ukraine_Russia_Europe_Gas_Oil_Factsheet.pdf.

6. Farah, Paolo Davide, Rossi, Piercarlo (2015). Energy: Policy, Legal and Social-Economic Issues Under the Dimensions of Sustainability and Security. World Scientific Reference on Globalisation in Eurasia and the Pacific Rim.

7. Hoffman K. (1979). Ekonomicheskaya otsenka prirodnykh resursov v usloviyakh sotsialisticheskoy ekonomiki [Economic evaluation of natural resources in a socialist economy]. In Voprosy teorii $i$ metodologii [Questions of theory and methodology]. M.: Nauka, $236 \mathrm{p}$.

8. IEA Statistics, Natural Gas Information (2014). Official site IEA. Available at http://www.iea.org/media/training/presentations/statisticsmarch/naturalgasinformation.pdf.

9. Jewell, J. (2011). The IEA Model of Short-term Energy Security (MOSES). Primary Energy Sources and Secondary Fuels. International Energy Agency.

10. Jakovez, Yu. (1984). Zakonomernosti nauchno-tekhnicheskogo progressa i ikh planomernoye ispol'zovaniye [Regularities of scientific and technological progress and their systematic use]. M.: Ekonomika, $240 \mathrm{p}$.

11. Krupneyshiye avarii na GES v mire za posledniye 50 let [Major accidents at the hydroelectric power station in the world over the past 50 years]. Available at http://expert.ru/ratings/table_531121/.

12. Lamben, J. J. (1996). Strategic marketing. European perspective. Spb.: Nauka, 589 p.

13. Ogarenko, Yu. S. et al. (2007). Problemy ugol'noy promyshlennosti strany i vybrosy parnikovykh gazov ot dobychi i potrebleniya uglya [Problems of the country's coal industry and greenhouse gas emissions from coal mining and consumption]. National Ecological Center of Ukraine. Available at http://climategroup.org.ua/wp-content/uploads/2007/07/problemy-ugleproma.pdf.

14. Okorokov, R. V. (2006). Rynochnyye preobrazovaniya v elektroenergetike: vozmozhnosti $i$ ugrozy [Market transformations in the electric power industry: opportunities and threats]. SPb.: Nauka, $252 \mathrm{p}$.

15. Political Risk 2013. Available at http://usa.marsh.com/Portals/9/Documents/Political\%20Risk\%20Map\%202013.pdf.

16. Reimers, N. F. (1990). Prirodopol'zovaniye: slovar'-spravochnik [Nature management: glossary]. M.: Mysl', $637 \mathrm{p}$.

17. Rutledge, I. (2006). Addicted to Oil: America's Relentless Drive for Energy Security. I. B. Tauris. ISBN 978-1-84511-319-3.

18. Shrum, T. (2007). Greenhouse Gas Emissions. In Policy and Economics. Available at http://www.carbontax.org/wp-content/uploads/2008/03/kansas-energy-council_ghgreview.pdf._Last access: 25 May, 2009. 
19. Sovacool, B. K., Brown, M. A. (2010). Competing Dimensions of Energy Security: An International Perspective. Annual Review of Environment and Resources, 35, 77. doi:10.1146/annurev-environ042509-143035.

20. Tsivatyi V.G. (2016). Role of Shale Gas in the Energy Policy of Ukraine. In: Zhiltsov S. (eds) Shale Gas: Ecology, Politics, Economy. The Handbook of Environmental Chemistry, 52. Springer, Cham.

21. Za 5 mis. 2015 roku Ukrayina znyzyla vydobutok vuhillya bil'she nizh na polovynu [For 5 months in 2015 Ukraine reduced coal production by more than half]. Available at http://news.finance.ua/ua/news/352825/za-5-mis-2015-roku-ukrayina-znyzyla-vydobutok-vugillya-bilsh-nizh-na-polovynu-dzherelo.

22. Website of the International Energy Agency. Available at http://www.iea.org/topics/energysecurity/.
23. What
is
Nelson
Index?
Defining
and
Definition.
Available

at http://www.businessdictionary.com/definition/Nelson-Index.html.

\section{Appendix}

Table 1. The assessment of energy risks in Ukraine for certain types of energy resources (risks of disruptions in supply energy)

\begin{tabular}{|c|c|c|c|c|c|c|}
\hline \multirow{2}{*}{\multicolumn{2}{|c|}{ Indicatior }} & \multicolumn{3}{|c|}{$\begin{array}{l}\text { The level of dependence of risks on supply } \\
\text { disruptions }\end{array}$} & \multirow{3}{*}{$\begin{array}{c}\mathrm{Sc}^{\text {max }} \\
6 \\
\end{array}$} & \multirow{3}{*}{$\begin{array}{r}\text { Sc } \\
7 \\
\end{array}$} \\
\hline & & $\begin{array}{c}\text { Low } \\
0 \text { point }\end{array}$ & $\begin{array}{c}\text { Medium } \\
1 \text { point } \\
\end{array}$ & $\begin{array}{c}\text { High } \\
2 \text { points } \\
\end{array}$ & & \\
\hline 1 & 2 & 3 & 4 & 5 & & \\
\hline \multirow{8}{*}{ 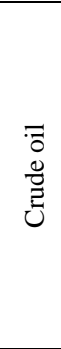 } & The dependence of the economy on the net import of crude oil & $\leq 15 \%$ & $40-65 \%$ & $\geq 80 \%$ & \multirow{8}{*}{16} & \multirow{8}{*}{12} \\
\hline & The level of political stability in the supplier countries & $7.5-10$ & $>5-<7.5$ & $<5$ & & \\
\hline & The number of ports for supply of crude oil & $>5$ & $2-4$ & 1 & & \\
\hline & The number of oil pipelines for the supply of crude oil & $5-9$ & $3-4$ & $1-2$ & & \\
\hline & The level of suppliers diversification & $>0.8$ & $0.3-0.8$ & $<0.3$ & & \\
\hline & The share of offshore production of crude oil & $\geq 90 \%$ & $15-90$ & $<15 \%$ & & \\
\hline & The volatility of prices for crude oil & $<20 \%$ & $20-40$ & $>40 \%$ & & \\
\hline & The availability of reserves and infrastructure for storing crude oil & $\geq 55$ & $20-55$ & $\leq 20$ & & \\
\hline \multirow{8}{*}{ 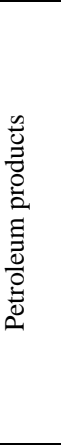 } & $\begin{array}{l}\text { The dependence of the economy of the studied country on the net } \\
\text { import of petroleum products }\end{array}$ & $\leq 45 \%$ & $40-65 \%$ & $\geq 65 \%$ & \multirow{4}{*}{16} & \multirow{4}{*}{9} \\
\hline & The Nelson index & $>0.8$ & $0.3-0.8$ & $<0.3$ & & \\
\hline & The number of ports for the supply of petroleum products & More than 5 & $2-4$ & 1 & & \\
\hline & The number of rivers for oil products supply & $5-9$ & $3-4$ & $1-2$ & & \\
\hline & The number of pipelines for oil products supply & $>0.8$ & $0.3-0.8$ & $<0.3$ & & \\
\hline & The number of refineries & $>2$ & $1-2$ & $<1$ & & \\
\hline & $\begin{array}{l}\text { The level of investment in the construction and modernization of } \\
\text { oil refining industry }\end{array}$ & $>9$ & $6-9$ & $<6$ & & \\
\hline & $\begin{array}{l}\text { The presence of reserves and infrastructure for the storage of } \\
\text { petroleum products, weeks }\end{array}$ & $\geq 9$ & $6-9$ & до 6 & & \\
\hline \multirow{6}{*}{ 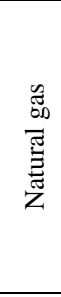 } & $\begin{array}{l}\text { The dependence of the economy of the studied country on the net } \\
\text { import of natural gas }\end{array}$ & $\leq 30 \%$ & $30-70 \%$ & $\geq 70 \%$ & \multirow{6}{*}{16} & \multirow{6}{*}{11} \\
\hline & The level of political stability in the supplying countries & $>0.8$ & $0.3-0.8$ & $<0.3$ & & \\
\hline & The number of ports for natural gas supplies & More than 3 & $1-2$ & 0 & & \\
\hline & The number of pipelines for natural gas supplies & More than 5 & $3-4$ & $1-2$ & & \\
\hline & The level of supplier diversification & $<0.3$ & $0.3-0.8$ & $>0.8$ & & \\
\hline & The share of offshore production of natural gas & $\geq 90 \%$ & $15-90 \%$ & $\leq 15 \%$ & & \\
\hline \multirow{9}{*}{ 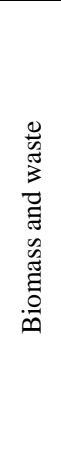 } & The share of domestic production of natural gas & $>100 \%$ & $50-100 \%$ & $<50 \%$ & & \\
\hline & The gas economy $=$ & $<20$ & $20-60$ & $>60$ & & \\
\hline & $\begin{array}{l}\text { The dependence of the economy of the studied country on the net } \\
\text { import of coal }\end{array}$ & 0 & $30-70 \%$ & $>70 \%$ & \multirow{5}{*}{10} & \multirow{5}{*}{2} \\
\hline & The number of ports for coal supply & $\geq 5$ & $31-4$ & $1-2$ & & \\
\hline & The number of railway stations for coal supply & 3 and more & 2 & 1 & & \\
\hline & The level of supplier diversification & $<0.3$ & $0.3-0.8$ & $>0.8$ & & \\
\hline & The share of coal mining & $<20 \%$ & $20-40 \%$ & $40-60 \%$ & & \\
\hline & $\begin{array}{l}\text { The dependence of the economy of the studied country on net } \\
\text { imports of biomass and waste }\end{array}$ & $0-12.5 \%$ & $12.5-25 \%$ & $>25 \%$ & \multirow[t]{2}{*}{4} & \multirow[t]{2}{*}{0} \\
\hline & The level of supplier diversification & $<0.3$ & $0.3-0.8$ & $>0.8$ & & \\
\hline
\end{tabular}


Table 1 (cont.). The assessment of energy risks in Ukraine for certain types of energy resources (risks of disruptions in supply energy)

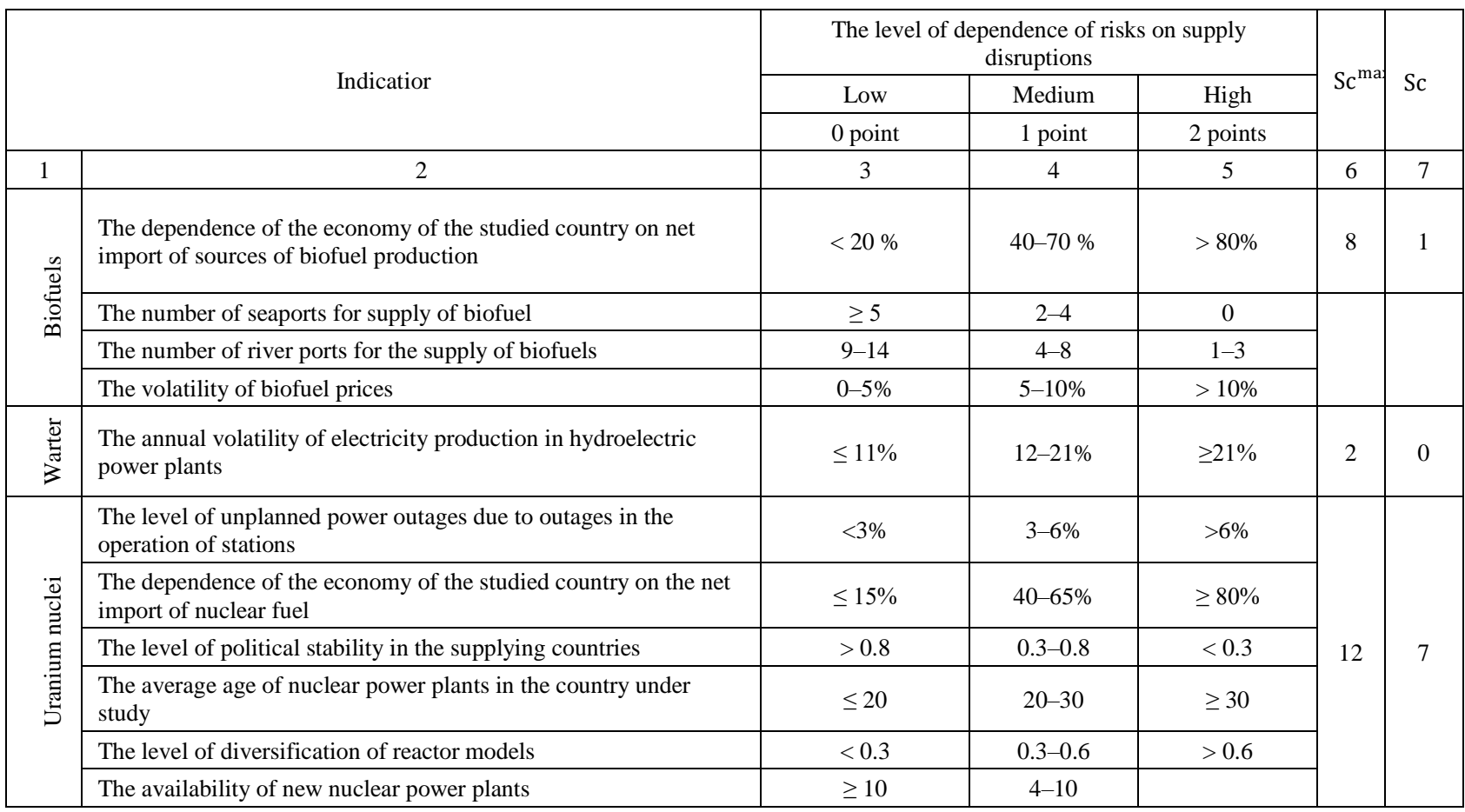

